\title{
Effect of Medicinal Herbs on Hematology of Fishes
}

\author{
K. V. Anjusha ${ }^{1}$, M. A. A. Mamun ${ }^{2,3^{*}}$, P. Dharmakar ${ }^{1}$ and N. Shamima ${ }^{2,4}$ \\ ${ }^{1}$ Department of Aquaculture, Fisheries College and Research Institute, \\ Thoothukudi, TNJFU, Tamil Nadu, India \\ ${ }^{2}$ Laboratory of Aquatic Health Management, Department of Aquaculture, College of \\ Fisheries, Mangalore-575002, Karnataka Veterinary Animal and Fisheries Science \\ University, Karnataka, India \\ ${ }^{3}$ Department of Fish Health Management, Sylhet Agricultural University, \\ Sylhet-3100, Bangladesh \\ ${ }^{4}$ Department of Fish Biology and Genetics, Sylhet Agricultural University, \\ Sylhet-3100, Bangladesh
}

*Corresponding author

\section{Keywords}

Medical herbs; Red blood cells;

Leucocyte counts; Aquaculture; Fishes

Article Info

Accepted:

22 August 2019

Available Online:

10 September 2019

\section{A B S T R A C T}

Medicinal plants have greater accuracy than chemotherapeutic agents because of their broad spectrum activity, cost effectiveness and eco-friendly disease preventive measure. The application of herbs in aquaculture has been a new approach. Medicinal herbs act as immunostimulants modulating the immune response to enhance health status of fish. Different scientific studies revealed that fishes fed with herbal plants showed marked increased of red blood cell, leucocyte counts and hemoglobin status. This article are illustrating the effect of herbal plants on the haematology of finfishes.

\section{Introduction}

Aquaculture is a steadily growing industry world over. The number of species and new technologies are increasing in aquaculture industry for raising production. Intensification has come up as a boon to meet the increasing food demand $(1,2)$. However, aquaculture industry has encountered repeated problems with disease during the past few years. Diseases have been an ongoing challenge for some large Asian aquaculture producers. The best way to prevent diseases and commercial losses of fish would be to improve their resistance to infections in addition to improving husbandry with good health management. The development of alternative practices for disease management is a big challenge. Recent research has begun to demonstrate the positive effect of the application of phytochemicals and herbal products in fish culture (3). 
Immunostimulatory plants can affect the hematological parameters and bactericidal activity of fish (4). Erythrocyte and hemoglobin play an important role in the transportation of oxygen and carbon dioxide.

Hematologic evaluation is one of the diagnostic tool for identifying diseases. Normal variation from intrinsic or extrinsic factors or diseases affecting blood cells and counts may be evaluated by clinical hematology (6). Most of the fish have nucleated erythrocytes which play an important role in oxygen transport, which depends on the amount of hemoglobin concentration within the cell and the gasexchange mechanism (7). Similar to other vertebrates, fish leucocytes involved in defense mechanism and provide protection against infections.

Globally fish and shellfish culture are subjected to many diseases that lead to great losses and decrease in food production. People understood the negative effect of antibiotics and they are now shifting over to natural products (8). Medicinal herbs incorporated diets can change hematological profile and improve well-being of fish.

Ginger at $1000 \mathrm{mg} / 35 \mathrm{~L}$ inclusion level increased erythrocyte count, hematocrit, hemoglobin, and lymphocytes count in Clarias gariepinus juveniles. An increase in hematological indices shows immune system stimulation and function of organs related to blood cell formation such as thymus, spleen, and bone marrow (9). Mangosteen (Garcinia mangostana) is one of the most widely recognized tropical fruit and widely known as "Queen of fruits". The pericarp (peel, rind, and hull) and the ripe fruit of mangosteen have been used as a traditional medicine. Incorporation of mangosteen at a dose of $5 \mathrm{~g} / \mathrm{kg}$ feed significantly enhance erythrocyte count in African catfish which might indicate an immunostimulant effect of the fruit. Mangosteen extract had no much impact on hemoglobin and increased levels of leucocytes considered as an indicator of the health status of fish (10).

Ginger and garlic supplemented diet enhanced hematological parameters (Red blood cells, hemoglobin, and white blood cells) of Husohuso at $1 \%$ inclusion level (11). Similarly, rainbow trout (Oncorhynchus mykiss) fed with a diet containing $1 \%$ powdered ginger rhizome (Zingiber officinale) showed a significant increase in immunostimulatory effect by inducing phagocytic activity of leucocytes and it increases the number of red blood cells and hematocrit value compared to the control group (12). Methanolic extract of tetra (Cotinus coggygria) at the level of $1 \mathrm{~g} / \mathrm{kg}$ feed increased erythrocyte count and mean corpuscular haemoglobin concentration of Koi carp. After challenge with Vibrio anguillarum the lowest mortality was observed in $1.5 \mathrm{~g} / \mathrm{kg}$ treated group. Hence, the oral administration of tetra extract protected the fish against Vibrio anguillarum(13).

Nettle or Urticadioica is a native herb in Europe, Asia, northern Africa and North America (14). In folk medicine, the aerial parts of nettle were used to treated anemia. Husohuso fed with nettle enriched diet at $12 \%$ inclusion level increased erythrocyte count, hematocrit and hemoglobin.

Mode of action of nettle on hematological indices could be due to the effect of its vitamin $\mathrm{C}$ on the increase of iron absorption from an intestine of fish (15). About neem (Azadirachta indica), its effectiveness in aquaculture depends greatly on factors such as the plant part, method of preparation, specific treatment application and method of application, dosage in relation to species and age. 
Fig.1 Parts of plants used in aquaculture (5)

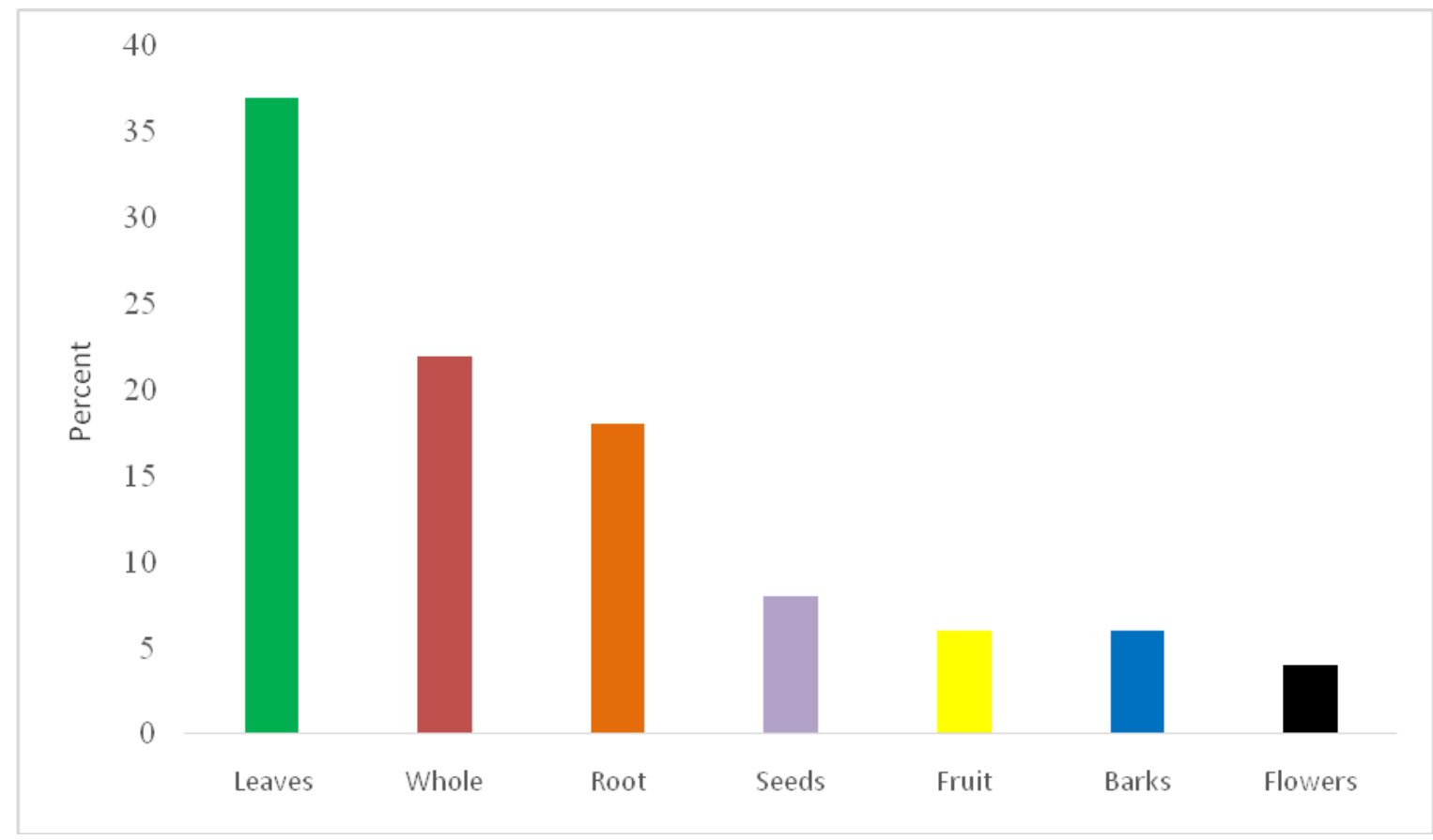

Fig. 2 Mode of action of medicinal plants in aquaculture (5)

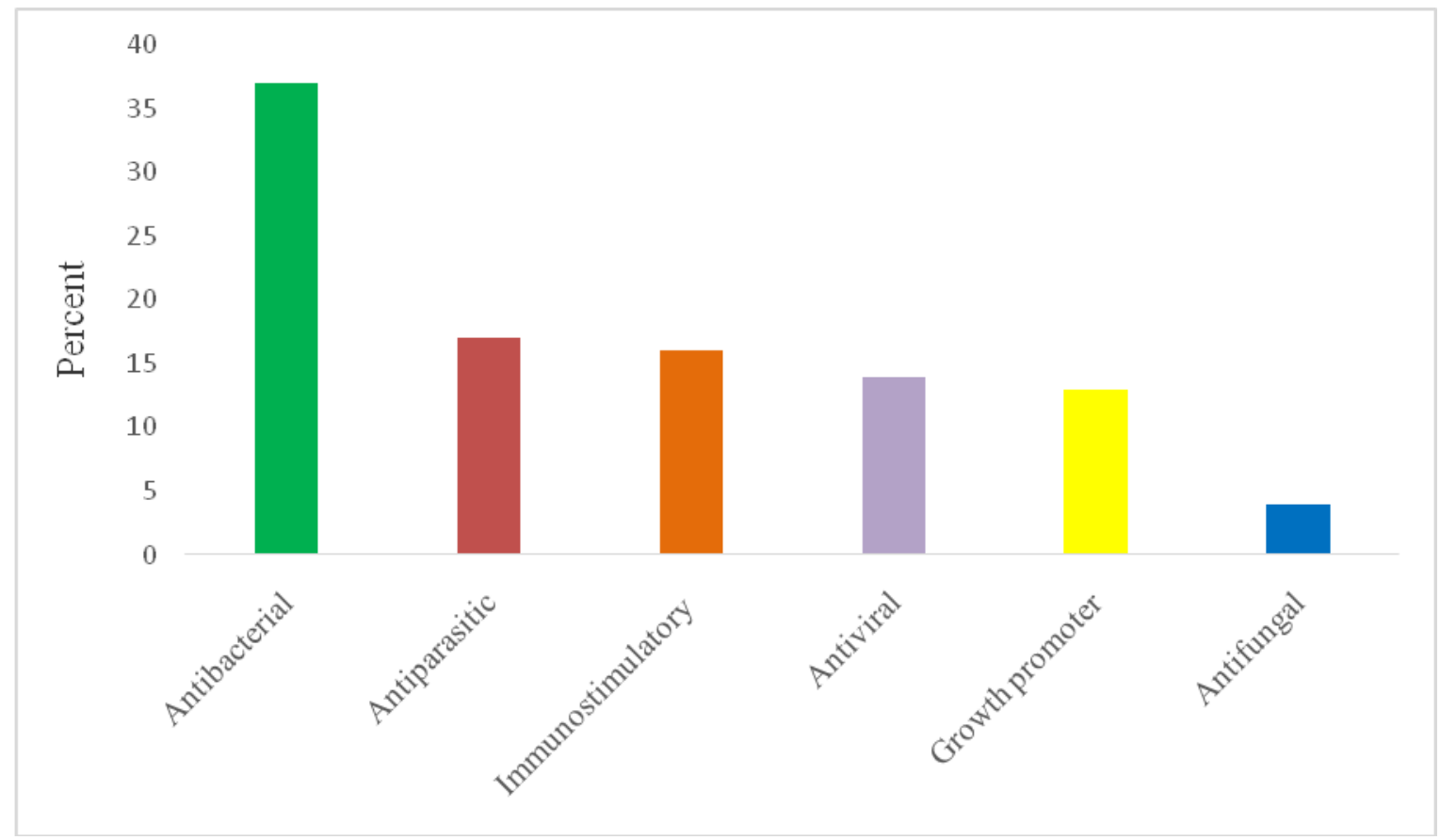


Cat fish fed with diet containing neem leaves aqueous extract presented lower haemoglobin, Red blood cell and packed cell volume compared to control. But it stimulated the production of circulating lymphocytes may be indicative of immune response readiness and hence suggestive of immune stimulation by neem extract (16).

A combination of herbs can enhance both specific and non-specific immune system. Goldfish (Carassius auratus) fed with diet containing Azadirachta indica, Ocimum sanctum and Curcuma longa at 400 or $800 \mathrm{mg} /$ $\mathrm{kg}$ altered hematological parameters and triggering the innate immune system against Aeromonas hydrophila (17). Rainbow trout (Oncorhynchus mykiss) supplemented with Echinacea purpurea caused significant increase in erythrocyte count, hematocrit and hemoglobin (18). This increase could be related to increasing cell nuclear contents of transcription factors (19).

Peppermint or Mentha piperita is a hybrid mint, a cross between watermint and spearmint. In Ayurveda this is an important ingredient of several compound formulations used in the management of gastrointestinal and skin disorders. Asian seabass (Lates calcarifer) fed with Mentha piperita incorporated diet at $5 \mathrm{~g} / \mathrm{kg}$ feed increased the number of erythrocytes (RBC), leucocytes (WBC) and hemoglobin significantly $(\mathrm{P}<0.05)$. Contrarily, after challenging with Vibrio harveyi leucocyte count increased and hemoglobin and erythrocyte count decreased (20). Epilobium hirsutum (willow herb) acts as both an immunostimulant and a disease control agent in fish. Common carp fed with Epilobium hirsutum containing feed increased leucocyte count before and after Aeromonas hydrophila infection. But erythrocyte, hemoglobin and hematocrit levels had no significant difference in infected and uninfected common carp fingerlings (21).

Very few evidences concerning the effect of garlic crusts on the health of animals. Garlic skins are contained pectin $(27 \%)$, combined rhamnose $(1.42 \%)$ and galactose $(5.6 \%)$. Beluga (Huso huso) fingerlings fed with garlic peel incorporated feed significantly $(\mathrm{p}<0.05)$ increased hemoglobin when compared to fish those fed with basal diet. There were no significant differences between erythrocyte counts, leucocyte count, hematocrit percentage, monocyte, lymphocyte, neutrophil and eosinophil count in fish fed with garlic peel incorporated diet compared with the control group (22).

Medicinal plants are effective and are alternative to antibiotics and chemotherapeutants. Most of the herbs can stimulate both specific and non-specific immune system by stimulating the production of blood cells and other hematological indices. Hence, phytotherapy is a safe and cheap method for treating fish diseases.

\section{Acknowledgements}

MM \& SN are gratefully acknowledge the funding received towards their Ph.D. from the Indian Council of Agricultural Research for awarded of Netaji Subhas- ICAR International fellowship 2015-16

\section{References}

1. Al Mamun MA, Nasren S, Bari SM. Role of Probiotics in Aquaculture: Importance and Future Guidelines. Journal of Bangladesh Academy of Sciences, 2018; 42(1): 105-109.

2. Mamun MAA, Nasren S, Abhiman PB, Rathore SS, Sowndarya NS, Ramesh KS, Shankar KM. Investigation of production, formation and characterization of biofilm cells of Aeromonas hydrophila for oral vaccination of fish. J. Exp. Zool. India, 2019; 22(2): 1115-1123

3. Rawling MD, Merrifield DL, Davies SJ. 
Preliminary assessment of dietary supplementation of Sangrovit $\AA$ on red tilapia (Oreochromis niloticus) growth performance and health. Aquaculture, 2009; 294(1-2), 118-122.

4. Nya EJ, Austin B. Use of garlic, Allium sativum, to control Aeromonas hydrophila infection in rainbow trout, Oncorhynchus mykiss (Walbaum). J. Fish Dis., 2009; 32(11): 963-970

5. Reverter M, Tapissier-Bontemps N, Sasal P, SaulnierD. 2017. Use of medicinal plants in aquaculture. Diagnosis and Control of Diseases of Fish and Shellfish, 1st Edn, Edt. Austin B., Newaj-Fyzul A., Chichester, UK: John Wiley \& Sons Ltd, 223-261.

6. Grant KR. Fish hematology and associated disorders. Veterinary Clinics: Exotic Animal Practice., 2015;18(1): 83103.

7. Fange R. Fish Blood Cells. In Fish physiology. Academic Press. 1992; 12: 154.

8. Fauci AS. Multifactorial nature of human immunodeficiency virus disease: implications for therapy. Science-new york then Washington.,1993; 262: 10111011

9. Iheanacho SC, Ogunji JO, Ogueji EO, Nwuba LA, Nnatuanya IO, Ochang SN, Haruna M. Comparative assessment of ampicillin antibiotic and ginger (Zingiber officinale) effects on growth, haematology and biochemical enzymes of Clariasgariepinus Juvenile. J. Pharmacog. Phytochem., 2007;6(3): 761767.

10. Soosean C, Marimuthu K, Sudhakaran S. XavierR. Effects of mangosteen (Garciniaman gostana L.) extracts as a feed additive on growth and haematological parameters of African catfish (Clarias gariepinus) fingerlings. Eur. Rev. Med.Pharma. Sci. 2010; 14: 605-611.
11. Kanani HG, Nobahar Z, Kakoolaki S,Jafarian H. Effect of ginger-and garlicsupplemented diet on growth performance, some hematological parameters and immune responses in juvenile Husohuso. Fish Physiol Biochem., 2014; 40(2): 481-490.

12. Haghighi M,RohaniMS. The effects of powdered ginger (Zingiber officinale) on the haematological and immunological parameters of rainbow trout Oncorhynchus mykiss. J. Med. Plants Res., 2013; 1(1): 8-12.

13. Bilen S, Yilmaz S,Bilen AM. Influence of tetra (Cotinuscog gygria) extract against Vibrio anguillarum infection in koi carp, Cyprinus carpio with reference to haematological and immunological changes. Turk $J$ Fish Aquat Sci. 201313(3): 517-522.

14. Borchers AT, Keen CL, Stern JS,Gershein ME. Inflammation and native American medicine: the role of botanicals. Am J ClinNutr., 2000; 72:339-347.

15. Lim C, Klesius $\mathrm{PH}, \mathrm{Li} \mathrm{MH}$, Robinson $\mathrm{EH}$. Interaction between dietary levels of iron and vitamin $\mathrm{C}$ on growth, hematology, immune response and resistance of channel catfish (Ictalurus punctatus) to Edwardsiella ictaluri challenge. Aquaculture, 2000; 185:31327.

16. OniovosaUE, Aina OO, Alarape SA, Babalola OE,AdeyemoOK. Effects of Neem Leaves Aqueous Extract on Organ Histology, Haematological Parameters and Biochemical Indices in Catfish. Alexandria $J$. of Veterinary Sci., 2017;54(1): 17-24.

17. Harikrishnan R, Balasundaram C, Heo MS. Herbal supplementation diets on hematology and innate immunity in goldfish against Aeromonas hydrophila. Fish Shellfish Immunol., 2010; 28(2): 354-361.

18. Oskoii SB, Kohyani AT, Parseh A, Salati 
AP, SadeghiE. Effects of dietary administration of Echinacea purpurea on growth indices and biochemical and hematological indices in rainbow trout (Oncorhynchus mykiss) fingerlings. Fish PhysiolBiochem., 201238(4): 1029-1034.

19. Sharma A, Deo AD, Riteshkumar T, Chanu TI, Das A. Effect of Withania somnifera (L. Dunal) root as a feed additive on immunological parameters and disease resistance to Aeromonas hydrophila in Labeorohita. Fish Shellfish Immunol., 2010;29:508-512.

20. Talpur AD. 2014. Mentha piperita (Peppermint) as feed additive enhanced growth performance, survival, immune response and disease resistance of Asian seabass, Lates calcarifer (Bloch) against
Vibrio harveyi infection. Aquaculture, 2014;420: 71-78.

21. Pakravan S, Hajimoradloo A,Ghorbani R. Effect of dietary willow herb, Epilobium hirsutum extract on growth performance, body composition, haematological parameters and Aeromonas hydrophila challenge on common carp, Cyprinuscarpio. Aqua Res., 2012; 43(6): 861-869.

22. Chitsaz H, Oraji H, KeramatAmirkolaei A, Akrami R. Effect of garlic peel on haematological, biochemical and digestive enzyme activity in beluga juvenile (Husohuso). I. J. Aqua. Anim.Health., 20184(1): 13-28.

\section{How to cite this article:}

Anjusha, K. V., M. A. A. Mamun, P. Dharmakar and Shamima, N. 2019. Effect of Medicinal Herbs on Hematology of Fishes. Int.J.Curr.Microbiol.App.Sci. 8(09): 2371-2376.

doi: https://doi.org/10.20546/ijcmas.2019.809.274 